American Journal of Agricultural and Biological Science 3(1): 410-416, 2008

ISSN 1557-4989

(C) 2008 Science Publications

\title{
Variations in Four Genotypes of Lentil under NaCl-Salinity Stress
}

\author{
M. Sidari, C. Santonoceto, U. Anastasi, G. Preiti and A. Muscolo \\ Department of Agricultural and Forest Systems Management, University Mediterranea of Reggio \\ Calabria Feo di Vito, -89060 Reggio Calabria, Italy
}

\begin{abstract}
Four lentil cultivars, Eston (E), Rossa of Castelluccio (RC), Pantelleria (P) and Ustica (U) differing in salt sensitivity, were examined for osmolyte contents and activities of $\alpha$-amylase, $\beta$-amylase and $\alpha$-glucosidase enzymes involved in seed germination, in absence as well as in presence of 50,100,150 and $200 \mathrm{mM} \mathrm{NaCl}$. The inhibitory effects of $\mathrm{NaCl}$ differed, depending on the genotypes tested. In Castelluccio and Eston, cultivars with reduced germination percentage and lower relative water content, the increase in $\mathrm{NaCl}$ concentration resulted in the decrease in endogenous levels of proline, total soluble sugars and activities of the main enzymes involved in the germination process. In contrast, Pantelleria and Ustica seeds in response to salt stress accumulated higher proline and total soluble sugar concentrations which improved their water status and the enzyme activities involved in the germination process. Differential response of the different genotypes of lentil to salt stress may be governed by the accumulation of osmolytes in seeds.
\end{abstract}

Key words: Amylases, glucosidase, proline, salt stress, seed germination

\section{INTRODUCTION}

The progressive salinization of land is one of the most severe world wide problems in agriculture production $^{[1,2]}$, being the major common abiotic stress for plant in arid or semiarid regions. Salts that generally are a common and necessary component of soil, essential plant nutrient, up to $45 \mathrm{ds} \mathrm{m}^{-1}(50 \mathrm{mM})$ can cause reduction in water availability, sodium ions accumulation and mineral imbalances that affect seed germination and plant metabolism ${ }^{[3]}$. All these factors manifest themselves by morphological, physiological and metabolic modifications in plant such as decrease in seed germination, decrease in shoot and root length ${ }^{[4]}$, alterations in the integrity of cell membranes, inhibition of different enzymatic activities and photosynthesis $^{[5]}$. Lentil (Lens culinaris M.) is considered a strategic crop under agronomic and food point of view, because of its role as possible component of the cropping systems in the Mediterranean areas and as a protein source for human and animal consumption ${ }^{[6,7,8]}$. The species is classified as salt sensitive $^{[9]}$ like many other leguminous. Selection for salinity resistance appears as a laborious and hazardous task and plant breeders are, therefore, seeking for quick, cheap and reliable ways to assess the salt-resistance of selected material. Determination of germination potential of seeds in saline conditions could appear as a simple and useful parameter for several reasons. First, salinity resistance at this stage was shown to be a heritable trait which could be used as an efficient criterion for the selection of salt-resistant populations ${ }^{[10]}$, although it is a polygenic character linked to a complex genetic basis ${ }^{[11]}$. Second, seeds and young seedlings are frequently confronted by much higher salinities than vigorously growing plants because germination usually occurs in surface soils which accumulate soluble salts as a result of evaporation and capillary rise of water. Several studies demonstrated that the evolution of salinity resistance is not the same for all cultivars of a given species ${ }^{[12,13]}$. Selection of salt tolerant lentil genotypes would allow one to cultivate this crop on saline soils or with saline waters which occur frequently in the Mediterranean areas.

Complex molecular responses including the accumulation of compatible solutes, the production of stress proteins and the expression of different sets of genes are part of the plant signalling and defence

Corresponding Author: Adele Muscolo, Dipartimento di Gestione dei Sistemi Agrari e Forestali Facoltà di Agraria Università Degli Studi Mediterranea di Reggio Calabria Feo di Vito 89060 Reggio Calabria Italy Tel: 0965/689012 Fax: 0965/312827 
system against salinity ${ }^{[5]}$. It is well known that one of the most common responses to salinity is the overproduction and accumulation of proline, glycine betaine and total sugars. Solute accumulation by cells is one such mechanism (osmoregulation) which contributes to stabilization of enzyme/protein ${ }^{[14]}$ and turgor maintenance ${ }^{[15]}$ in growing organs and has been correlated with productivity under stress ${ }^{[16]}$. In the present study, four genotypes of lentil with different salinity tolerance ${ }^{[17]}$ were studied to determine factors responsible for failure of germination. To fulfil such an aim, the effects of different $\mathrm{NaCl}$ concentrations were evaluated on relevant biochemical processes associated with seed germination.

\section{MATERIALS AND METHODS}

Plant materials: The experiment included three lentil landraces, Pantelleria, Ustica and Castelluccio di Norcia and a variety Eston. In particular, Pantelleria and Ustica are native of the homonymous small islands close to Sicily (Southern Italy); Castelluccio di Norcia is a traditional local population of Umbria (Central Italy), whereas Eston is a Canadian commercial variety recently introduced in Italy.

Germination condition: Seven months old well stored $\left(20 \pm 1^{\circ} \mathrm{C}\right.$ and $\left.\pm 5 \% \mathrm{RU}\right)$ seeds of each lentil genotype used in the experiment were surface-sterilized for 20 min in $30 \%(\mathrm{v} / \mathrm{v}) \mathrm{H}_{2} \mathrm{O}_{2}$, rinsed and soaked in distilled water for $1 \mathrm{~h}$. Fifty representative seeds per cultivar were placed on a filter paper in $9 \mathrm{~cm}$ Petri dishes containing $3 \mathrm{~cm}^{3}$ of distilled water (control), or 50, 100, 150 and $200 \mathrm{mM} \mathrm{NaCl}$. The Petri dishes were hermetically sealed with parafilm to prevent evaporation and then care kept in a humidity chamber at a temperature of $25 \pm 1^{\circ} \mathrm{C}$ in the dark. The seeds were considered germinated when there was radicle protrusion through the seed coat. In order to determine the dry weight, twenty-five seeds of each cultivar, were taken out and were dried at $70^{\circ} \mathrm{C}$ in an oven till there is no decrease in weight.

Enzyme assays and osmolytes content: Alpha-, betaamylase and alpha-glucosidase activities in the crude extracts of each cultivar were determined. The seeds of each cultivar, in deionised water (control) and treated with different concentrations of $\mathrm{NaCl}(50,100,150$, $200 \mathrm{mM}$ ) were homogenised in a chilled mortar with distilled water 1:4 (w/v) and centrifuged at $14000 \mathrm{~g}$ for $30 \mathrm{~min}$. The supernatants were filtered through a single layer of muslin cloth and were used for $\alpha$-amylase (EC 3.2.1.1) $)^{[18]}, \beta$-amylase (EC 3.2.1.2 $)^{[19]}, \alpha$-glucosidase (EC 3.2.1.20) ${ }^{[19]}$ estimation.

For determination of proline contents seeds were hand-homogenized in $3 \%$ of sulfosalicylic acid and centrifuged at $3000 \mathrm{~g}$ at $4^{\circ} \mathrm{C}$ for $10 \mathrm{~min}$. The supernatants were used for proline estimation ${ }^{[20]}$.

The total soluble sugars were determined with the anthrone method ${ }^{[21]}$.

Experimental design and statistical analysis: Data were analyzed separately for each genotype by one way procedure of ANOVA $(\mathrm{p} \leq 0.05)$ according to a completely randomized design with five replicates. Treatment means were compared using the StudentNewman-Keul test $(\mathrm{p} \leq 0.05)^{[22]}$.

\section{RESULTS}

Germination of all cultivars began from $24 \mathrm{~h}$ after sowing, reaching germination percentage higher than $98 \%$ in control seeds. Salinity caused a delay in germination that was different among the cultivars. At 48 and $72 \mathrm{~h}$ the germination percentage of Castelluccio and Eston under salinity was significantly lower compared to Pantelleria and Ustica. However, at $200 \mathrm{mM} \mathrm{NaCl}$, final germination percentage was significantly reduced in Eston $(50 \%)$ and even more in Castelluccio $(10 \%)$ cultivars, while under control condition 100 and $98 \%$ germination occurred for both cultivars, respectively. The cultivars Pantelleria and Ustica germinated more than the other ones (74 and $82 \%$ ), exhibiting a fair degree of salt tolerance. Increasing salinity a gradual decrease in the RWC in all cultivars was observed. The lower water content was detected in Castelluccio and Eston genotypes ${ }^{[17]}$.

The proline content of Pantelleria and Ustica cultivars was enhanced at different salt concentrations (Fig. 1). The highest amount of proline was observed at 150 and $200 \mathrm{mM} \mathrm{NaCl}$ for both cultivars. Interestingly, Pantelleria and Ustica accumulated two times more proline than Castelluccio and Eston (Fig. 1).

The level of total soluble sugars increased to a smaller extent over stressed seeds of Castelluccio and Eston cultivars. On the contrary, as a consequence of stress, in Pantelleria and Ustica genotypes, increasing salinity a gradual increase in total soluble sugars was observed.

Salinity had pronounced effects on $\alpha$-amylase, $\beta$ amylase and $\alpha$-glucosidase activities. The activity of these enzymes decreased in a dose-dependent manner, differing among the cultivars. The effect of salinity was more pronounced in seeds of cultivars Eston and even more Castelluccio.

$\beta$-amylase and $\alpha$-glucosidase activities showed also a decreasing trend with the increase in $\mathrm{NaCl}$ concentration. The activities of $\beta$-amylase and $\alpha$ glucosidase in stressed seeds of Pantelleria and Ustica were higher compared to those detected in Castelluccio and Eston genotypes (Table 1-3). 
Am. J. Agri. \& Biol., 3(1): 410-416, 2008

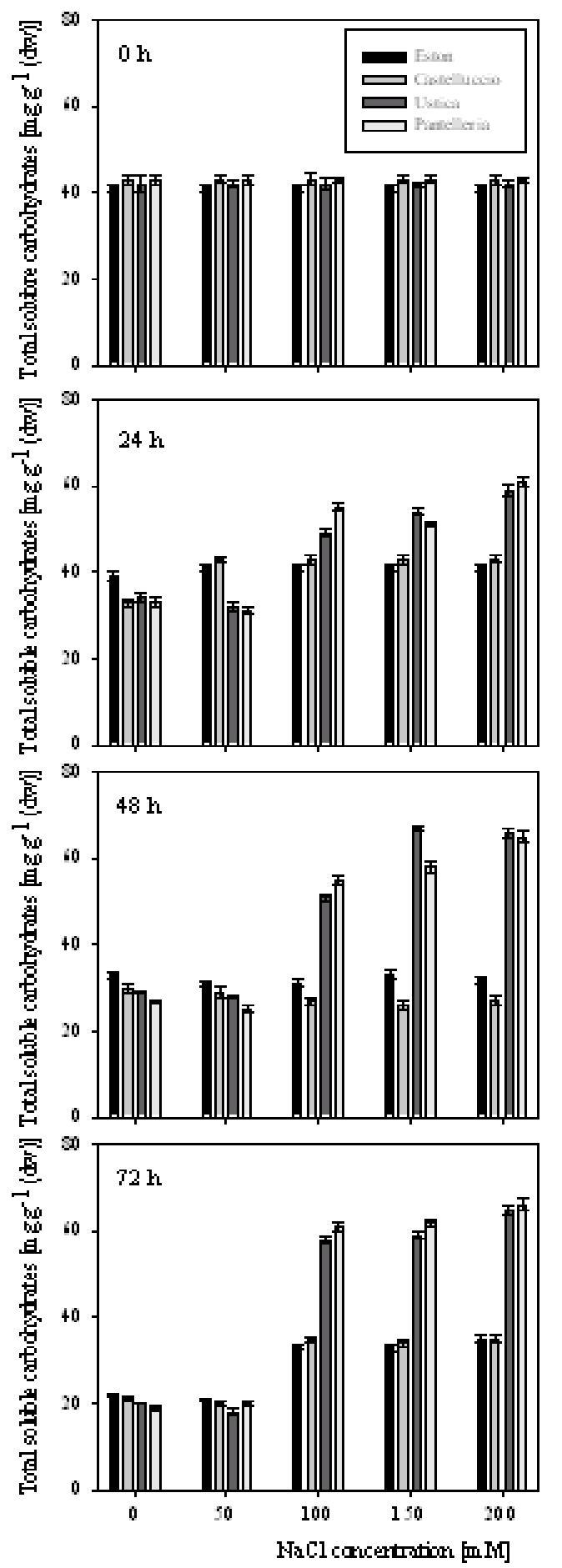

A
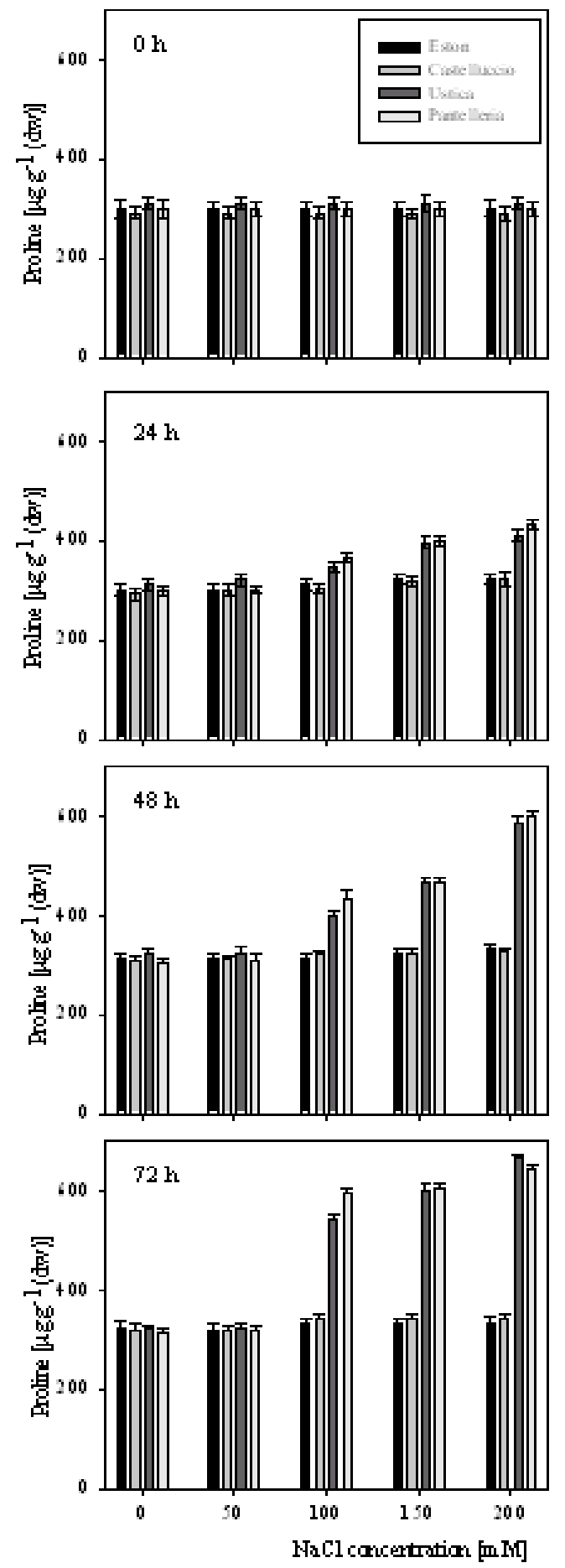

B

Fig. 1: Total soluble carbohydrates (A) and proline content (B) in Eston, Castelluccio di Norcia, Ustica and Pantelleria lentil cultivar seeds in $0,50,100,150$ and $200 \mathrm{mM} \mathrm{NaCl}$ at $0,24,48$ and 72 hours. Vertical bars indicate $\mathrm{SD}(\mathrm{n}=5)$ 
Am. J. Agri. \& Biol., 3(1): 410-416, 2008

Table 1: $\alpha$-Amylase, $\beta$-amylase and $\alpha$-glucosidase activities in control and in lentil cultivars: Eston (Canadian commercial variety), Castelluccio di Norcia (traditional local population of Central Italy), Pantelleria and Ustica (native of the homonymous small islands in Southern Italy) that had been exposed for $24 \mathrm{~h}$ to different salt concentrations. Enzyme activities are expressed as $\mu$ moles of reducing sugars formed $\min ^{-1} \mathrm{~g}^{-1} \mathrm{fw}$

\begin{tabular}{lllcrrr}
\hline & & Treatments & & & \\
Enzymes & cv. & Control & $50 \mathrm{mM}$ & $100 \mathrm{mM}$ & $150 \mathrm{mM}$ & $200 \mathrm{mM}$ \\
\hline$\alpha$-amylase & Eston & $16.10 \mathrm{a}$ & $15.43 \mathrm{ab}$ & $14.01 \mathrm{~b}$ & $10.50 \mathrm{~b}$ & $8.10 \mathrm{c}$ \\
& Castelluccio & $17.20 \mathrm{a}$ & $4.50 \mathrm{~b}$ & $4.05 \mathrm{~b}$ & $1.91 \mathrm{~d}$ & $2.04 \mathrm{c}$ \\
& Ustica & $26.11 \mathrm{a}$ & $26.51 \mathrm{a}$ & $22.93 \mathrm{~b}$ & $19.04 \mathrm{c}$ & $17.96 \mathrm{~d}$ \\
& Pantelleria & $26.43 \mathrm{a}$ & $26.25 \mathrm{a}$ & $24.39 \mathrm{~b}$ & $18.18 \mathrm{c}$ & $16.00 \mathrm{~d}$ \\
$\beta$-amylase & Eston & $0.75 \mathrm{a}$ & $0.41 \mathrm{~b}$ & $0.44 \mathrm{~b}$ & $0.21 \mathrm{c}$ & $0.18 \mathrm{~d}$ \\
& Castelluccio & $0.70 \mathrm{a}$ & $0.21 \mathrm{~b}$ & $0.21 \mathrm{~b}$ & $0.11 \mathrm{c}$ & $0.10 \mathrm{c}$ \\
& Ustica & $1.00 \mathrm{~b}$ & $1.15 \mathrm{a}$ & $1.01 \mathrm{~b}$ & $1.11 \mathrm{a}$ & $1.14 \mathrm{a}$ \\
\multirow{3}{*}{$\alpha$-glucosidase } & $0.98 \mathrm{c}$ & $1.40 \mathrm{a}$ & $1.11 \mathrm{~b}$ & $1.10 \mathrm{~b}$ & $0.84 \mathrm{~d}$ \\
& Pantelleria & $0.271 \mathrm{a}$ & $0.280 \mathrm{a}$ & $0.190 \mathrm{~b}$ & $0.091 \mathrm{c}$ & $0.081 \mathrm{c}$ \\
& Eston & $0.220 \mathrm{a}$ & $0.091 \mathrm{~b}$ & $0.041 \mathrm{c}$ & $0.031 \mathrm{~d}$ & $0.011 \mathrm{e}$ \\
& Castelluccio & $0.301 \mathrm{a}$ & $0.294 \mathrm{~b}$ & $0.291 \mathrm{~b}$ & $0.190 \mathrm{c}$ & $0.100 \mathrm{~d}$ \\
& Ustica & $0.310 \mathrm{a}$ & $0.281 \mathrm{~b}$ & $0.290 \mathrm{~b}$ & $0.189 \mathrm{c}$ & $0.095 \mathrm{~d}$ \\
\hline
\end{tabular}

Mens in the same row with the same letter are not significantly different at $\mathrm{p} \leq 0.05$

Table 2: $\alpha$-Amylase, $\beta$-amylase and $\alpha$-glucosidase activities in control and in lentil cultivars: Eston (Canadian commercial variety), Castelluccio di Norcia (traditional local population of Central Italy), Pantelleria and Ustica (native of the homonymous small islands in Southern Italy) that had been exposed for $48 \mathrm{~h}$ to different salt concentrations. Enzyme activities are expressed as $\mu$ moles of reducing sugars formed $\min ^{-1} \mathrm{~g}^{-1} \mathrm{fw}$

\begin{tabular}{llllllr}
\hline & & Treatments & & & \\
Enzymes & cv. & Control & $50 \mathrm{mM}$ & $100 \mathrm{mM}$ & $150 \mathrm{mM}$ & $200 \mathrm{mM}$ \\
\hline$\alpha$-amylase & Eston & $16.40 \mathrm{a}$ & $16.30 \mathrm{a}$ & $15.01 \mathrm{~b}$ & $13.25 \mathrm{c}$ & $6.10 \mathrm{~d}$ \\
& Castelluccio & $15.50 \mathrm{a}$ & $4.50 \mathrm{~b}$ & $4.55 \mathrm{~b}$ & $2.01 \mathrm{c}$ & $2.04 \mathrm{c}$ \\
& Ustica & $27.11 \mathrm{a}$ & $26.90 \mathrm{a}$ & $21.03 \mathrm{~b}$ & $19.04 \mathrm{c}$ & $15.66 \mathrm{~d}$ \\
& Pantelleria & $26.10 \mathrm{a}$ & $27.25 \mathrm{~b}$ & $23.39 \mathrm{c}$ & $20.18 \mathrm{~d}$ & $13.95 \mathrm{e}$ \\
$\beta$-amylase & Eston & $0.92 \mathrm{a}$ & $0.49 \mathrm{~b}$ & $0.51 \mathrm{~b}$ & $0.29 \mathrm{c}$ & $0.21 \mathrm{~d}$ \\
& Castelluccio & $0.81 \mathrm{a}$ & $0.29 \mathrm{~b}$ & $0.27 \mathrm{c}$ & $0.15 \mathrm{~d}$ & $0.12 \mathrm{e}$ \\
& Ustica & $1.41 \mathrm{a}$ & $1.21 \mathrm{~b}$ & $1.19 \mathrm{~b}$ & $1.01 \mathrm{~d}$ & $1.15 \mathrm{c}$ \\
\multirow{3}{*}{$\alpha$-glucosidase } & $1.30 \mathrm{~b}$ & $1.61 \mathrm{a}$ & $1.21 \mathrm{c}$ & $1.24 \mathrm{bc}$ & $0.92 \mathrm{~d}$ \\
& Pantelleria & $0.281 \mathrm{a}$ & $0.296 \mathrm{a}$ & $0.193 \mathrm{~b}$ & $0.095 \mathrm{c}$ & $0.090 \mathrm{c}$ \\
& Eston & $0.230 \mathrm{a}$ & $0.091 \mathrm{~b}$ & $0.049 \mathrm{c}$ & $0.039 \mathrm{~d}$ & $0.016 \mathrm{e}$ \\
& Castelluccio & $0.321 \mathrm{a}$ & $0.300 \mathrm{~b}$ & $0.296 \mathrm{~b}$ & $0.200 \mathrm{c}$ & $0.101 \mathrm{~d}$ \\
& Ustica & $0.318 \mathrm{a}$ & $0.290 \mathrm{~b}$ & $0.294 \mathrm{~b}$ & $0.192 \mathrm{c}$ & $0.096 \mathrm{~d}$ \\
\hline
\end{tabular}

Means in the same row with the same letter are not significantly different at $\mathrm{p} \leq 0.05$

Table 3: $\alpha$-Amylase, $\beta$-amylase and $\alpha$-glucosidase activities in control and in lentil cultivars: Eston (Canadian commercial variety), Castelluccio di Norcia (traditional local population of Central Italy), Pantelleria and Ustica (native of the homonymous small islands in Southern Italy) that had been exposed for $72 \mathrm{~h}$ to different salt concentrations. Enzyme activities are expressed as $\mu$ moles of reducing sugars formed $\min ^{-1} \mathrm{~g}^{-1} \mathrm{fw}$

\begin{tabular}{lllcccc}
\hline & & Treatments & & & & \\
Enzymes & cv. & Control & $50 \mathrm{mM}$ & $100 \mathrm{mM}$ & $150 \mathrm{mM}$ & $200 \mathrm{mM}$ \\
\hline$\alpha$-amylase & Eston & $16.43 \mathrm{a}$ & $17.43 \mathrm{a}$ & $15.43 \mathrm{~b}$ & $13.7 \mathrm{c}$ & $7.80 \mathrm{~d}$ \\
& Castelluccio & $12.083 \mathrm{a}$ & $1.085 \mathrm{~b}$ & $1.054 \mathrm{~b}$ & $1.045 \mathrm{~b}$ & $1.049 \mathrm{~b}$ \\
& Ustica & $24.97 \mathrm{a}$ & $24.58 \mathrm{a}$ & $21.43 \mathrm{~b}$ & $14.84 \mathrm{c}$ & $16.76 \mathrm{~d}$ \\
& Pantelleria & $26.03 \mathrm{a}$ & $25.03 \mathrm{~b}$ & $25.39 \mathrm{~b}$ & $21.86 \mathrm{c}$ & $15.90 \mathrm{~d}$ \\
$\beta$-amylase & Eston & $1.16 \mathrm{a}$ & $0.58 \mathrm{~b}$ & $0.59 \mathrm{~b}$ & $0.31 \mathrm{c}$ & $0.27 \mathrm{~d}$ \\
& Castelluccio & $0.98 \mathrm{a}$ & $0.35 \mathrm{~b}$ & $0.32 \mathrm{c}$ & $0.21 \mathrm{~d}$ & $0.16 \mathrm{e}$ \\
& Ustica & $1.74 \mathrm{a}$ & $1.45 \mathrm{~b}$ & $1.35 \mathrm{c}$ & $1.16 \mathrm{~d}$ & $1.16 \mathrm{~d}$ \\
\multirow{3}{*}{$\alpha$-glucosidase } & $1.45 \mathrm{~b}$ & $1.74 \mathrm{a}$ & $1.36 \mathrm{c}$ & $1.32 \mathrm{c}$ & $0.98 \mathrm{~d}$ \\
& Pantelleria & $0.298 \mathrm{a}$ & $0.301 \mathrm{a}$ & $0.211 \mathrm{~b}$ & $0.101 \mathrm{c}$ & $0.098 \mathrm{c}$ \\
& Eston & $0.133 \mathrm{a}$ & $0.102 \mathrm{~b}$ & $0.054 \mathrm{c}$ & $0.043 \mathrm{~d}$ & $0.021 \mathrm{e}$ \\
& Castelluccio & $0.345 \mathrm{a}$ & $0.302 \mathrm{~b}$ & $0.300 \mathrm{~b}$ & $0.211 \mathrm{c}$ & $0.110 \mathrm{~d}$ \\
& Ustica & $0.320 \mathrm{a}$ & $0.298 \mathrm{~b}$ & $0.298 \mathrm{~b}$ & $0.201 \mathrm{c}$ & $0.102 \mathrm{~d}$ \\
\hline
\end{tabular}

Means in the same row with the same letter are not significantly different at $\mathrm{p} \leq 0.05$. 


\section{DISCUSSION}

Genetic variability within a species offers a valuable tool for studying mechanism of salt tolerance. Our results show a decrease in germination and vigour of seeds in all studied genotypes, with increasing salinity. In the cultivars Castelluccio and, in minor extent, in Eston the magnitudes of such decrease were more as compared to that of cultivars Ustica and Pantelleria, in particular way when high salinity concentrations were used. The germination process can be considered in terms of three sequential steps: imbibition, metabolism leading to initiation of radicle growth and radicle growth leading to radicle emergence. A threshold level of hydration is required for the synthesis of hydrolitic enzymes which are responsible for the hydrolysis of stored substrates. The hydrolyzed products are utilized in seedling tissue synthesis and radicle elongation ${ }^{[23]}$. In lentil seeds, the role of providing utilizable substrates is taken over mainly by amylases. Inhibition of germination due to salinity as suggested in previous reports ${ }^{[24,25,17]}$ is attributed to a decrease water content, that affect the synthesis of hydrolitic enzymes limiting the hydrolysis of food reserves from storage tissues as well as to impaired translocation of food reserves from storage tissue to developing embryo axis ${ }^{[26,27]}$. It can be also hypothesized that the presence of $\mathrm{NaCl}$ at low concentrations, which is penetrating ions, could have contributed to a decrease in the internal osmotic potential of germinating structures, as suggested by Dodd and Donovan ${ }^{[28]}$ and Almasouri et al. ${ }^{[13]}$ leading to water uptake and initiation of germination processes. Our results indicate a lower content of total soluble sugar and proline in presence of the highest salt concentration in Castelluccio and Eston compared to Ustica and Pantelleria cultivars, suggesting that salt tolerance ability of these two last landraces appears to be associated to the accumulation of osmolytes which improved their water status. Salt stress has been reported to limit the mobilization of starchy endosperm reserves in several species, as a result of inhibition of different enzymatic activities ${ }^{[29,30]}$. Starch mobilization results from simultaneous activities of $\alpha$-amylase, $\beta$ amylase and $\alpha$-glucosidase. In germinating seeds, starch degradation is initiated by $\alpha$-amylase ${ }^{[31]}$, that produces soluble oligosaccharides from starch and these are then hydrolyzed by $\beta$-amylase to liberate maltose. Finally, $\alpha$ glucosidase breaks down maltose into glucose, the main respiratory substrate ${ }^{[32]}$. Numerous works correlated germination performance with $\alpha$-amylase, but in a study of the comparative importance of $\alpha$ and $\beta$-amylase in determining germination ability, Das and Sen-Mandi ${ }^{[33]}$ demonstrated greater importance of $\beta$-amylase compared to $\alpha$-amylase, during the early hours of germination in wheat scutella. In addition, Nandi et al. ${ }^{[34]}$ showed that $\beta$-amylase activity becomes detectable immediately before visible germination becomes evident, whereas $\alpha$-amylase activity is initiated at later stage of germination, suggesting that $\alpha$-amylase affects rate of seedling growth while $\beta$-amylase activity is associated with initiation of germination. Therefore, $\beta$-amylase is a crucial and essential enzyme for germination. Our results show that high salt concentrations adversely affected each enzyme in all genotypes examined. Nevertheless in this work $\beta$ amylase activity was always significantly lower in Castelluccio and Eston compared to their own control and salt treated Pantelleria and Ustica at every concentration used. In addition also when Castelluccio and Eston were treated with low salt concentration $(50 \mathrm{mM}), \beta$-amylase activity at $72 \mathrm{~h}$ was lower than that detected at $24 \mathrm{~h}$ in their own control or in Pantelleria and Ustica salt treated seeds at every concentration used, suggesting that this enzyme could be salt sensitive related. The variation in stress sensitivity of contrasting lentil genotypes may be linked to their ability to osmoregulate under stress, which cause a strong decrease in water content affecting the hydrolytic enzyme activities, particularly $\beta$-amylase levels. $\beta$ amylase is probably synthesized during imbibition, in fact a seed hydratation pre-treatment in rice or other cereals species, that enhances seed vigour was found also to bring about an enhancement in $\beta$-amylase activity $^{[34]}$. Thus, data presented in all these reports provide support for the view that the higher $\beta$-amylase activity in Pantelleria and Ustica cv. might be the cause for the major seed germination in presence of $\mathrm{NaCl}$ salinity.

Some important conclusions can be drawn from the results achieved during this experiment. Although lentil is considered a very sensitive specie to salinity, much more than other legumes such as broadbean and soybean, we have identified two cultivars, Ustica and Pantelleria, found in a southern Italian semiarid environment, that could be utilized not only in breeding programs to improve the saline resistance of the species but also to be cultivated in environments where salinity of the soils is a frequent constraint.

\section{ACKNOWLEDGEMENTS}

This study was supported by the Università Mediterranea di Reggio Calabria, Programmi di Ricerca 
Scientifica (ex Quota 60\%). The authors thank Mrs. Aileen Cummins for revising the language.

\section{REFERENCES}

1. Greenway, H. and R. Munns, 1980. Mechanism of salt tolerance in nonhalophytes. An. Rev. Plant Physiol., 31: 149-190.

2. Pandey, A.N. and N.K. Thakares, 1997. Effect of chloride salinity on survival and growth of Prosopis chilensis seedlings. Trop. Ecol., 3: 145-148.

3. Ali, H., T.C. Tucher, T.L. Thompson and M. Salim, 2001. Effects of salinity and mixed ammonium and nitrate nutrition on the growth and nitrogen utilization of barley. J. Agron. Crop Sci., 186: 223-228.

4. Arshi, A., M.Z. Abdin and M. Iqbal, 2002. Growth and metabolism of senna as affected by salt stress. Biol. Plant., 45: 295-298.

5. Sairam, R.K. and A. Tyagi, 2004. Physiology and molecular biology of salinity stress tolerance in plants. Curr. Sci., 86: 407-421

6. Kurdali, F., K. Kalifo and M. Al Schamma, 1997. Cultivar differences in nitrogen assimilation, partitioning and mobilization in rain-fed grown lentil. Field Crops Res., 54: 235-243.

7. Thomson, B.D. and K.H.N. Siddique, 1997: Grain legume species in low rainfall Mediterranean type environments. II. Canopy development, radiation interception and dry matter production. Field Crops Res., 54: 173-187.

8. Katerji, N., J.W. van Hoorn, A. Hamdy, M. Mastrorilli, T., Oweis and W. Erskine, 2001. Response of two varieties of lentil to soil salinity. Agric. Water Manage., 47: 179-190.

9. Ashraf, M. and A. Waheed, 1990. Screening of local/exotic accessions of lentil (Lens culinaris) for salt tolerance at two growth stages. Plant Soil, 128: 167-176.

10. Ashraf, M., T. McNeilly and A.D. Bradshaw, 1987. Selection and heritability of tolerance to sodium chloride in four forage species. Crop Sci., 227: 232-234.

11. Mano, Y. and K. Takeda, 1997. Mapping quantitative trait loci for salt tolerance at germination and seedling stage in barley (Hordeum vulgare L.). Euphytica, 94: 263-272.

12. Lutts, S., J.M. Kinet and J. Bouharmont, 1995. Changes in plant response to $\mathrm{NaCl}$ during development of rice (Oryza sativa L.) varieties differing in salinity resistence. J. Exp. Bot., 46: $1843-1852$.

13. Almansouri, M., J.M. Kinet and S. Lutts, 2001. Effect of salt and osmotic stresses on germination in durum wheat (Triticum durum Desf.). Plant Soil, 231: 243-254.
14. Bohnert, H.J., D.E. Nelson and R.G. Jensen, 1995. Adaptation to environmental stresses. Plant Cell, 7: 1099-1111.

15. Morgan, J.M., 1992. Osmotic components and properties associated with genotypes differences in osmoregulation in wheat. Aust. J. Plant Physiol., 19: 67-76.

16. Cushman, J.C., 2001. Osmoregulation in plants: Implications in agriculture. Am. Zool., 41: 758-769.

17. Sidari, M., A. Muscolo, U. Anastasi, G. Preiti and C. Santonoceto, 2007. Response of four genotypes of lentil to salt stress conditions. Seed Sci. Technol. (In Press).

18. Coombe, B.G., D. Choen and L.G. Paleg, 1967. Barley endosperm for gibberellin. I. Parameters of response system. Plant Physiol., 42: 641-645.

19. Bergmeyer, H.U., M. Graß1 and H.E. Walter, 1983. Enzymes. In: Methods of Enzymatic Analysis. Bergmeyer, H.U., J. Bergmeyer and M. Graß1 (Eds.), pp: 126-328, Verlag Chemie, Weinheim.

20. Bates, L.S., R.P. Waldren and I.D. Teare, 1973. Rapid determination of free proline for water stress studies. Plant Soil, 39: 205-207.

21. Yemn, E.W. and A.J. Willis, 1954. The estimation of carbohydrates in plant extracts by anthrone. Biochem. J., 57: 508-514.

22. Sokal, R.R. and F.J. Rohlf, 1969. Biometry. 1st Edn., Freeman and Co., pp: 1-776.

23. Ramagopal, S., 1990. Inhibition of seed germination by salt and its subsequent effect on embryonic protein synthesis in barley. J. Plant Physiol., 136: 621-625.

24. Ghoulam, C. and K. Fares, 2001. Effect of salinity on seed germination and early seedling growth of sugar beet. Seed Sci.Technol., 29: 357-364.

25. Niazi, M.L.K., K. Mahovo, S.M. Mujtaba and K.A. Malik, 1992. Salinity tolerance in different cultivars of barley (Hordeum vulgare, L.). Biol. Plant., 34: 5-6.

26. Dubey, R.S. Effect of salinity on nucleic acid metabolism of germinating rice seeds differing in salt tolerance. Plant Physiol. Biochem., 12: 9-16.

27. de Lacerda, C.F., J. Cambraia, M.A. Oliva, H.A. Ruiz and J. Tarquinio Prisco, 2003. Solute accumulation and distribution during shoot and leaf development in two sorghum genotypes under salt stress. Environ. Exp. Bot., 49: 107-120.

28. Dodd, G.L. and L.A. Donovan, 1999. Water potential and ionic effects on germination and seedling growth of two cold desert shrubs. Am. J. Bot., 86: 1146-1153. 
29. Lin, C.C. and C.H. Kao, 1995. $\mathrm{NaCl}$ stress in rice seedlings: starch mobilization and the influence of gibberellic acid on seedling growth. Bot. Bull. Acad. Sin., 36: 169-173.

30. Almasouri, M., J.M. Kinet and S. Lutts, 1999. Compared effects of sudden and progressive imposition of salt stress in three durum wheat (Triticum durum Desf.) cultivars. J. Plant Physiol., 154: 743-752.

31. Yamasaki, Y., 2003. $\beta$-Amylase in germinating millet seeds. Phytochemistry, 64: 935-939.
32. Nomura, T., Y. Kono and T. Akazawa, 1969. Enzyme mechanism of starch breakdown in germinating rice seeds. II. Scutellum as the site of sucrose synthesis. Plant Physiol., 44: 765-769.

33. Das, G. and S. Sen-Mandi, 1992. Scutellar amylase activity in naturally aged and accelerated aged wheat seeds. An. Bot. 69: 497-501.

34. Nandi, S., G. Das and S. Sen-Mandi, 1995. $\beta$-Amylase activity as an index for germination potential in rice. An. Bot., 75: 463-467. 